\title{
ДОСЛІДЖЕННЯ ФЛАВОНОЇДІВ ЧОРНОБРИВЦІВ ЗОЛОТИСТИХ (TAGETES LUCIDA CAV.)
}

Вступ. Перспективним джерелом одержання нових лікарських препаратів є види роду Чорнобривці (Tagetes), які культивують в Україні як технічну та декоративну рослину. Чорнобривці, завдяки їх лікувальним властивостям, використовують у традиційній медицині як імунозміцнювальний, протизапальний, гіпоглікемічний, жовчогінний та заспокійливий засіб. Маловивченим видом роду Tagetes є чорнобривці золотисті (Tagetes lucida Cav.). В Україні його ввели в культуру науковці відділу квітниково-декоративних рослин Національного ботанічного саду імені М. М. Гришка НАН України (м. Київ).

Мета дослідження - вивчити і порівняти вміст фрлавоноїдів у сировині (квітках, листках, коренях, насінні, стеблах) чорнобривців золотистих.

Методи дослідження. Флавоноїди виявляли в етанольно-водних витяжках за допомогою реакцій ідентифрікації та методом тонкошарової хроматографії (ТШХ). Кількісний вміст суми фрлавоноїдів визначали на спектрофротометрі "UV-1800 Shimadzu” (Японія) за довжини хвилі 415 нм у перерахунку на рутин. Кількісний вміст індивідуальних фрлавоноїдних сполук виявляли і визначали методом високоефективної рідинної хроматографої (BEPX) на хроматографрі “Agilent 1200" (“Agilent Technologies”, США).

Результати й обговорення. Позитивні результати реакцій ідентифрікації свідчили про наявність фрлавоноїдів у сировині чорнобривців золотистих. Методом ТШХ встановлено наявність у квітках, листках, коренях, насінні й стеблах кверцетину і кемпферолу. Рутин виявлено в усіх досліджуваних видах сировини, крім стебел. Методом ВЕРХ у чорнобривців золотистих квітках та насінні виявлено по 6 індивідуальних фрлавоноїдів, у листках - 5, у коренях і стеблах - по 4. Найбільше у досліджуваних об'єктах виявлено кверцетину. В насінні, листках та квітках його вміст був найвищим і становив 6322,13 мкг/2, 4006,79 мкг/2 та 3734,08 мкг/2 відповідно. Усі види сировини чорнобривців золотистих містили також кемпферол, якого найбільще у квітках - 303,29 мкг/2. Спектрофотометричним методом визначено, що найвищий вміст суми фрлавоноїдів є в насінні рослини, і він становить $(7,89 \pm 0,18) \%$, найменше їх у стеблах - $(1,86 \pm 0,08) \%$.

Висновки. Реакціями ідентифрікації встановлено наявність фрлавоноїдів у чорнобривців золотистих квітках, листках, коренях, насінні й стеблах. Методом ТШХ виявлено кверцетин, кемпорерол, рутин (крім стебел), ізокверцитрин (крім коренів), апігенін (лише у квітках). Методом ВЕРХ у чорнобривців золотистих квітках та насінні виявлено по 6 індивідуальних фрлавоноїдів, у листках - 5, у коренях і стеблах - по 4. Найбільше удосліджуваних об'єктах виявлено кверцетину. Спектрофотометричним методом визначено кількісний вміст суми фрлавоноїдів у сировині чорнобривців золотистих. Найвищий він у насінні - $(7,89 \pm 0,18) \%$, дещо нижчий у листках - $(6,58 \pm 0,12) \%$.

КЛЮчОВІ СЛОВА: чорнобривці золотисті (Tagetes lucida Cav.); фрлавоноїди; тонкошарова хроматографія; високоефективна рідинна хроматографія; спектроскопія.

ВСТУП. Важливим джерелом одержання лікарських засобів є лікарські рослини. На сьогодні близько 25 \% лікарських препаратів, які застосовують у медичній практиці в усьому світі, отримують 3 лікарської рослинної сировини $[1,2]$.

Перспективним джерелом одержання нових лікарських препаратів є види роду Чорнобривці (Tagetes) з родини айстрові (Asteraceae), які містять значну кількість біологічно активних

(c) С. М. Марчишин, Л. В. Костишин, Т. В. Валько, В. М. Кіщук, Е. А. Паращук, 2021. речовин. Види роду Чорнобривці широко культивують в Україні як технічну та декоративну рослину. Чорнобривці, завдяки лікувальним властивостям, використовують у традиційній медицині для покращення гостроти зору, при цукровому діабеті, як імунозміцнювальний, протизапальний, гіпоглікемічний, жовчогінний та заспокійливий засіб [3-6].

Встановлено, що біологічна активність лікарських засобів із сировини роду Чорнобривці пов'язана $з$ наявністю в рослинах сполук фенольної природи, одними з яких є фрлавоноїди 
[3, 6-10]. Флавоноїдам властива висока і різноманітна біологічна активність: Р-вітамінна (капілярозміцнювальна), антиоксидантна, протизапальна, репаративна, діуретична, гепатопротекторна, гіпоглікемічна, гіполіпідемічна, спазмолітична та ін. [11, 12].

Маловивченим видом роду Tagetes є чорнобривці золотисті (чорнобривці анісові, естрагон мексиканський - Tagetes lucida Cav.). В Україні його ввели в культуру науковці відділу квітниково-декоративних рослин Національного ботанічного саду імені М. М. Гришка НАН України (м. Київ). Попередні дослідження хімічного складу чорнобривців золотистих показали, що вони містять ефірну олію, дубильні речовини, жирні кислоти, амінокислоти, гідроксикоричні кислоти $[13,14]$. Флавоноїди цього виду роду Чорнобривці вивчено недостатньо, тому метою нашого дослідження було вивчити і порівняти вміст даної групи біологічно активних речовин у сировині (квітках, листках, коренях, насінні, стеблах) чорнобривців золотистих.

МЕТОДИ ДОСЛІДЖЕННЯ. Матеріалом дЛя досліджень були квітки, листки, корені, насіння та стебла чорнобривців золотистих (Tagetes lucida Cav.), які заготовляли на дослідних ділянках відділу квітниково-декоративних рослин Національного ботанічного саду ім. М. М. Гришка НАН України. Траву (стебла, листки, квітки) заготовляли в липні - серпні 2021 р. у період масового цвітіння рослин, насіння і корені - при дозріванні насіння в серпні - вересні.

Флавоноїди виявляли в етанольно-водних витяжках досліджуваної сировини за допомогою реакцій ідентифрікації (ціанідинова проба; з 10 \% етанольно-водним розчином калій гідрооксиду; $310 \%$ розчином ферум (III) хлориду; $310 \%$ розчином плюмбум ацетату) $[15,16]$.

Наступним етапом ідентифрікації фрлавоноїдів була тонкошарова хроматограсрія (ТШХ). Використовували рухому фазу - н-бутанол $\mathrm{P}$ - ацетатна льодяна кислота P - вода очищена P (4:1:2), хроматографічні пластинки "Сорбфріл" (Sorbfil peates розміром $10 \times 15$, Росія) і стандартні фрармакопейні зразки (ФСЗ) фрлавоноїдів: рутин, апігенін, кемпоерол, кверцетин, лютеолін та гіперозид. Хроматограми висушували і розглядали при денному й УФ-світлі до та після обробки парами аміаку [16].

Ідентифікацію проводили, порівнюючи значення Rf фрлавоноїдів, які $€$ у досліджуваній сировині, зі значеннями Rf стандартних зразків, i за забарвленням плям у денному й УФ-світлі до та після обробки хроматограм парами аміаку.

Кількісний вміст суми фрлавоноїдів визначали спектрофотометричним методом на спект- рофотометрі "UV-1800 Shimadzu" (Японія) за довжини хвилі 415 нм у перерахунку на рутин $[16,17]$ та абсолютно суху сировину у відсотках (X) і розраховували за формулою:

$$
\mathrm{X}=\frac{\mathrm{D} \times \mathrm{m}_{0} \times 30 \times 100 \times 100}{\mathrm{D}_{0} \times \mathrm{m} \times(100-\mathrm{W}) \times 100},
$$

де $D$ - оптична густина випробуваного розчину;

$\mathrm{D}_{0}$ - оптична густина стандартного зразка рутину;

m - маса наважки сировини, г;

$\mathrm{m}_{0}$ - маса наважки ФСЗ ДФУ рутину, г;

W - втрата в масі при висушуванні, \% [15].

Методом високоесрективної рідинної хроматограсрії (BEPX) $[16,17]$ у сировині чорнобривців золотистих на хроматографрі "Agilent 1200" ("Agilent Technologies", США) виявляли і визначали кількісний вміст індивідуальних фрлавоноїдних сполук.

Екстрагували 0,2-0,6 г сировини кожної проби в 10 мл $70 \%$ етанолу на ультразвуковій бані за температури $80{ }^{\circ} \mathrm{C}$ впродовж 5 год у скляних герметичних віалах із тефрлоновою кришкою. Одержаний екстракт центрисугували при 3000 об./хв та фрільтрували крізь одноразові мембранні фрільтри з порами 0,22 мкм.

Як рухому фазу використовували ацетонітрил (А) та 0,1 \% розчин мурашиної кислоти у воді (В). Елюювали в градієнтному режимі: 0 хв A (30\%) : B (70 \%); 20 XB - A (70 \%) : B (30\%); $22 \times B-A(100 \%)$ : B (0\%); 30 ×B - A (100\%) : В (0 \%). Розділення здійснювали на хроматографрічній колонці Zorbax SB-C18 (3,5 мкм, 150×4,6 мм) (“Agilent Technologies", США), швидкість потоку через колонку - 0,25 мл/хв, температура термостата $-30^{\circ} \mathrm{C}$, об'єм інжекції - 4 мкл. Детекцію проводили з використанням діодноматричного детектора з реєстрацією сигналу при 280 і 365 нм та фріксацією спектрів поглинання в діапазоні 210-700 нм [18, 19].

Ідентифрікацію та кількісний аналіз здійснювали із застосуванням стандартних розчинів срлавоноїдів (рутину, ізокверцитрину, нарингіну, неогесперидину, кверцетину, нарингеніну, кемпфреролу, лютеоліну, апігеніну).

Кількість фрлавоноїдів (Х) (мкг/г) визначали за формулою:

$$
\mathrm{X}=\frac{\mathrm{C} \times \mathrm{V}}{\mathrm{m}},
$$

де C - концентрація сполуки, визначена хроматограсрічним методом, мкг/мл;

V - об'єм екстракту, мл;

m - маса сировини, г.

РЕЗУЛЬТАТИ Й ОБГОВОРЕННЯ. ПОЗИТИВНі результати реакцій ідентисрікації свідчили про 
наявність фрлавоноїдів у досліджуваній сировині. Методом ТШХ було встановлено наявність у квітках, листках, коренях, насінні й стеблах кверцетину і кемпореролу. Рутин виявлено в усіх досліджуваних видах сировини чорнобривців золотистих, крім стебел. Ізокверцитрин не виявлено в коренях. У квітках спостерігали сліди апігеніну. Плями на хроматограмах були жовтого та жовто-коричневого кольору, їх значення Rf збігалися зі значеннями Rf стандартних зразків фолавоноїдів. Не виявлено у досліджуваній сировині лютеоліну і гіперозиду.
У досліджуваній сировині чорнобривців 3олотистих методом ВЕРХ виявлено індивідуальні фрлавоноїди і встановлено їх кількісний вміст. Результати досліджень наведено на рисунках 1-5 і в таблиці 1.

Експериментально встановлено, що у чорнобривців золотистих квітках та насінні виявлено по 6 індивідуальних фрлавоноїдів, у листках - 5, у коренях і стеблах - по 4. Найбільше у досліджуваних об'єктах виявлено кверцетину. В насінні, листках та квітках його вміст був найвищим і становив 6322,13 мкг/г, 4006,79 мкг/г та 3734,08 мкг/г

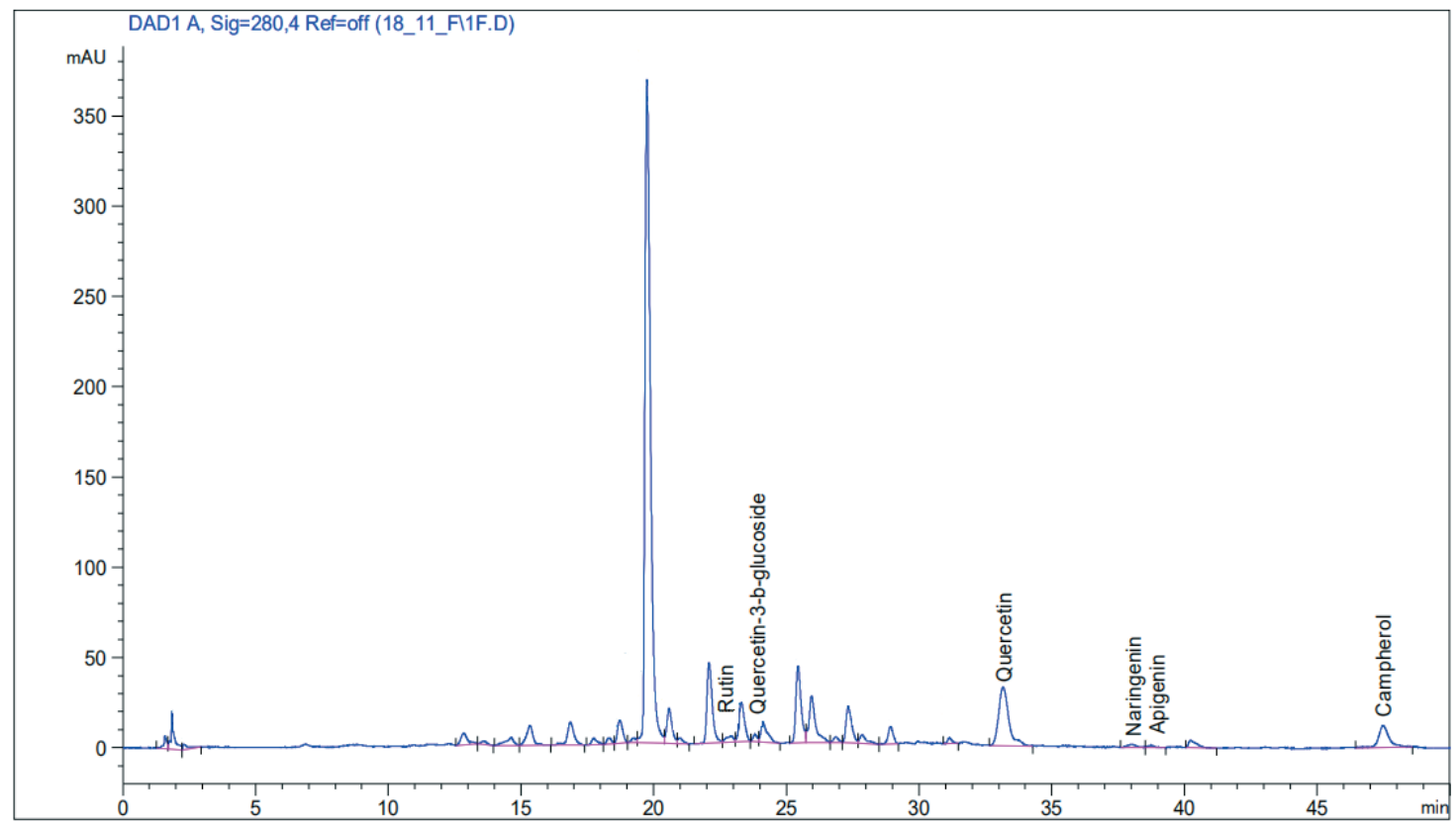

Рис. 1. ВЕРХ-хроматограма срлавоноїдів чорнобривців золотистих квіток.

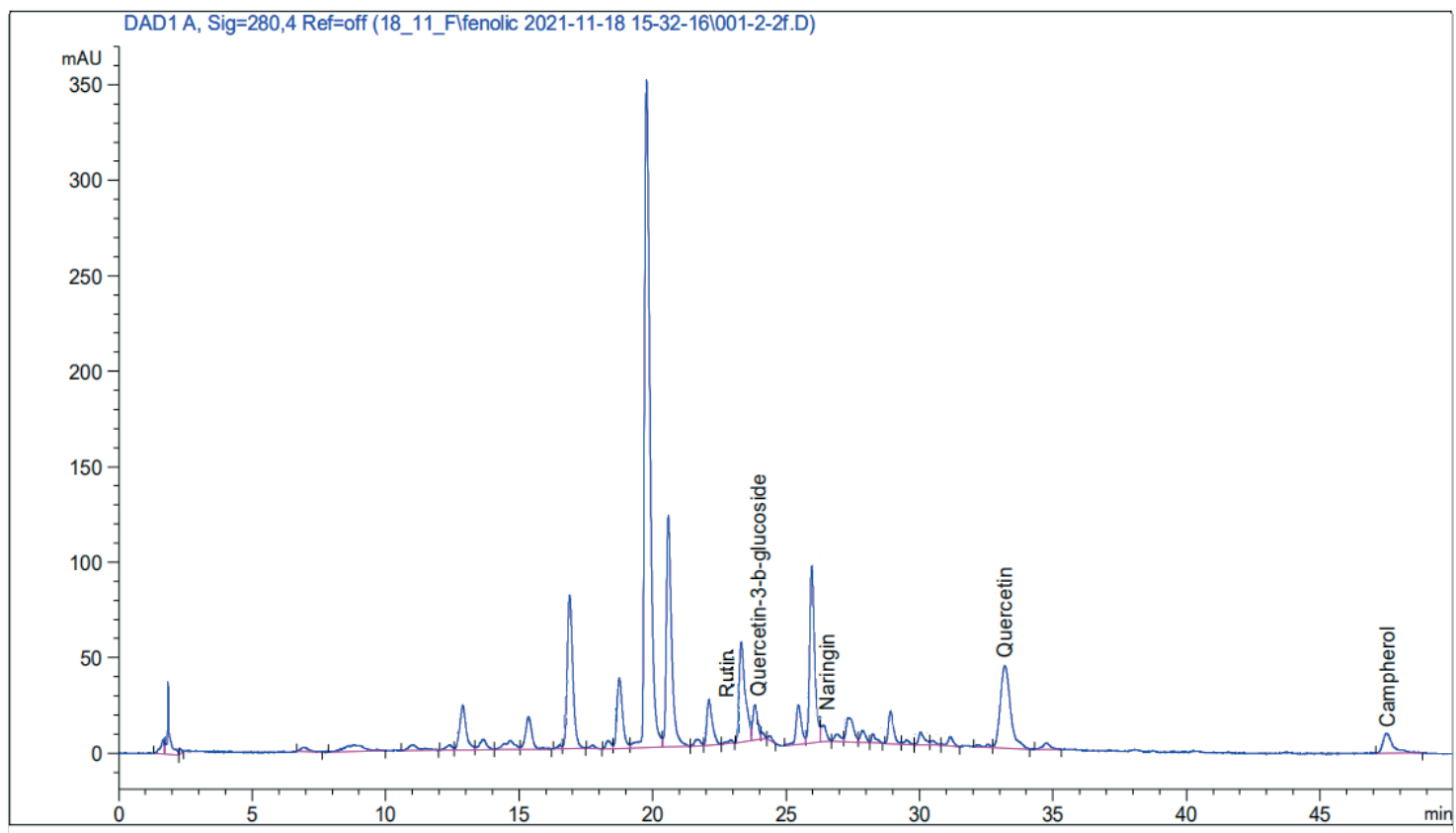

Рис. 2. ВEPX-хроматограма фрлавоноїдів чорнобривців золотистих листків. 


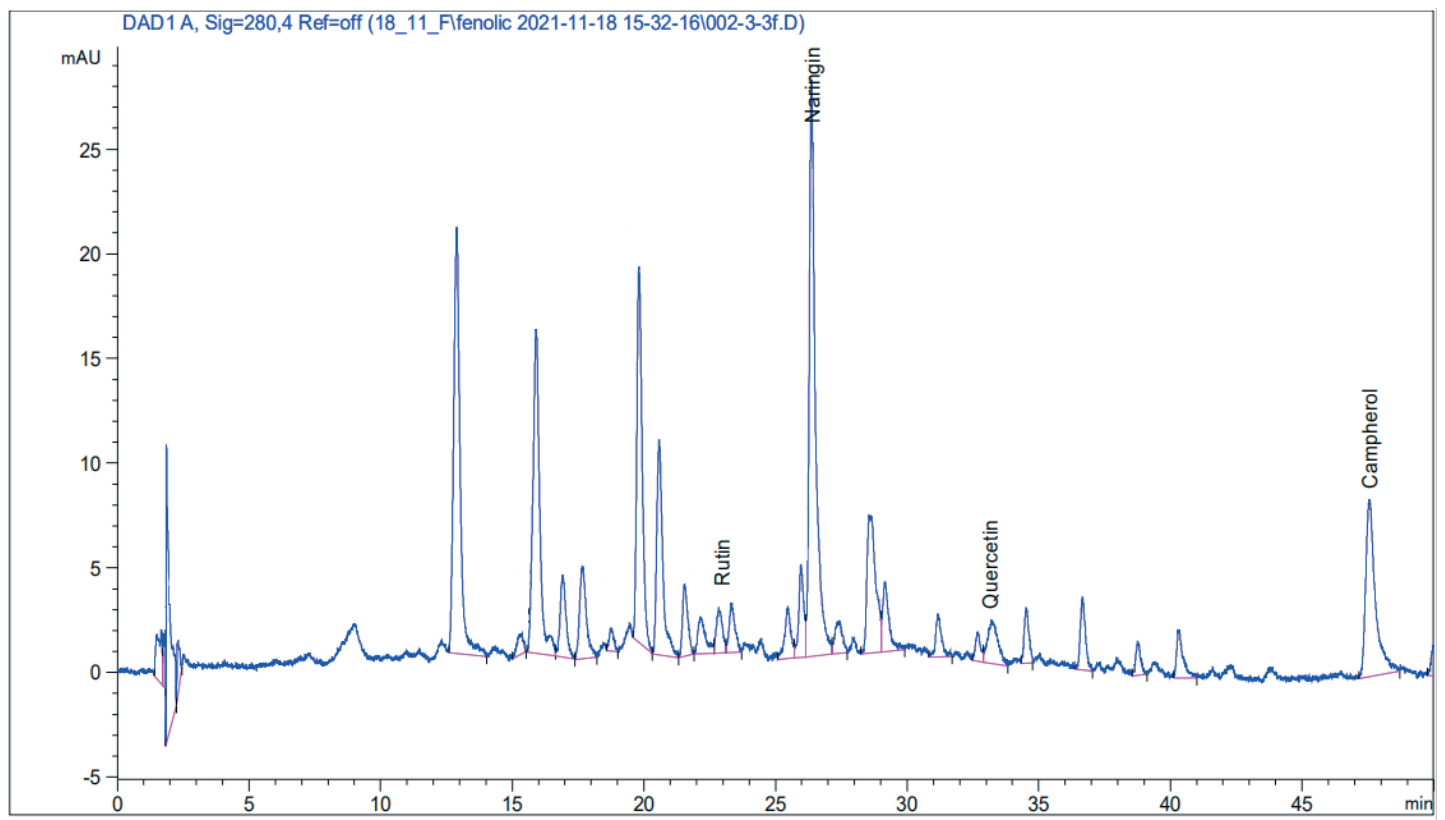

Рис. 3. ВЕРХ-хроматограма фрлавоноїдів чорнобривців золотистих коренів.

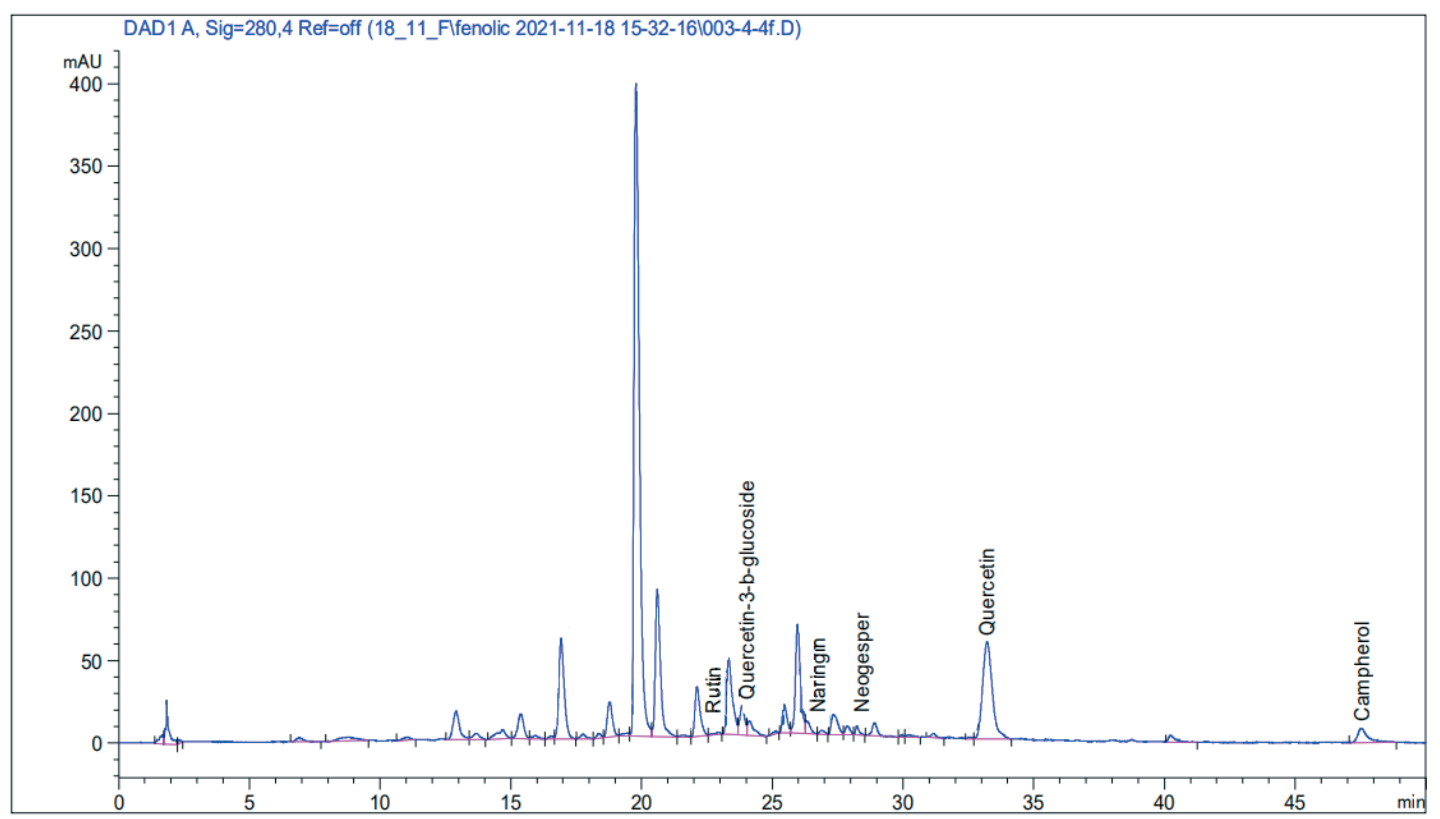

Рис. 4. ВЕРХ-хроматограма фрлавоноїдів чорнобривців золотистих насіння.

відповідно. Найменше кверцетину було в коренях 220,44 мкг/г. У коренях спостерігали найбільшу кількість нарингіну - 1773,97 мкг/г, якого не виявлено у чорнобривців золотистих квітках (табл. 1).

Результати досліджень, наведені в таблиці 1, також вказують на те, що всі види сировини чорнобривців золотистих містили не лише кверцетин, а й кемпоерол, якого найбільше у квітках 303,29 мкг/г. Найменше кемпфреролу спостерігали у стеблах рослини, що становило 136,71 мкг/г. Апігенін і нарингенін виявлено тільки у чорнобривців золотистих квітках - 90,44 та 192,78 мкг/г відповідно; неогесперидин -лише в насінні, його вміст становив 219,22 мкг/г. У стеблах не виявлено ру- тину, який наявний у всіх інших досліджуваних видах сировини. Найбільше його спостерігали у квітках - 247,04 мкг/г.

У сировині чорнобривців золотистих спектрофотометричним методом визначено кількісний вміст суми срлавоноїдів у перерахунку на рутин. Результати досліджень наведено в таблиці 2.

Результати досліджень показали, що вміст суми фрлавоноїдів найбільшим був у чорнобривців золотистих насінні - $(7,89 \pm 0,18) \%$, найменше їх у стеблах рослини - $(1,86 \pm 0,08) \%$. Вміст суми фллавоноїдів у квітках і листках був у 1,9 й 1,2 раза меншим, ніж у насінні, і становив $(4,15 \pm 0,18)$ та $(6,58 \pm 0,12) \%$. 


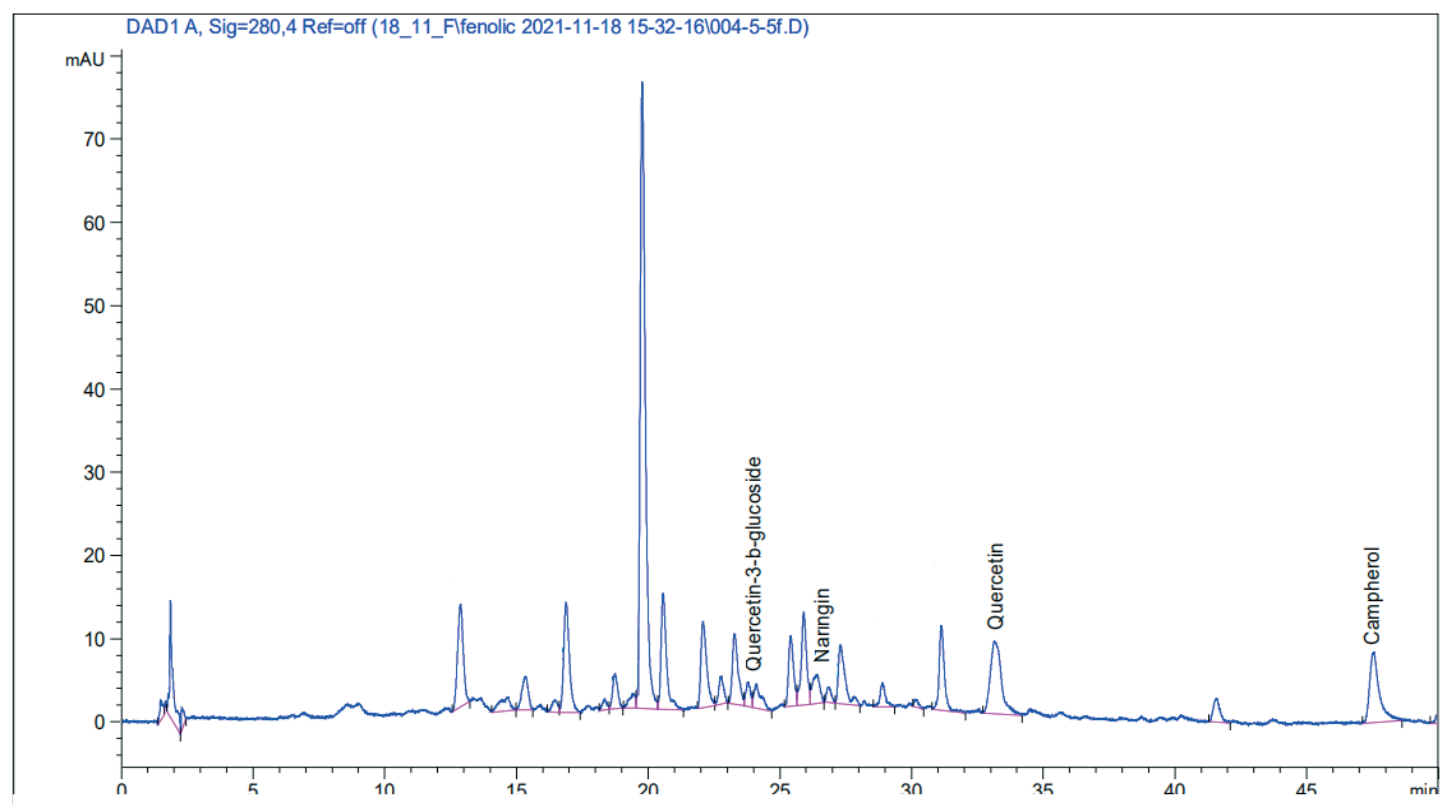

Рис. 5. ВЕРХ-хроматограма фрлавоноїдів чорнобривців золотистих стебел.

Таблиця 1 - Якісний склад і кількісний вміст флавоноїдів у сировині чорнобривців золотистих (метод високоефективної рідинної хроматографії)

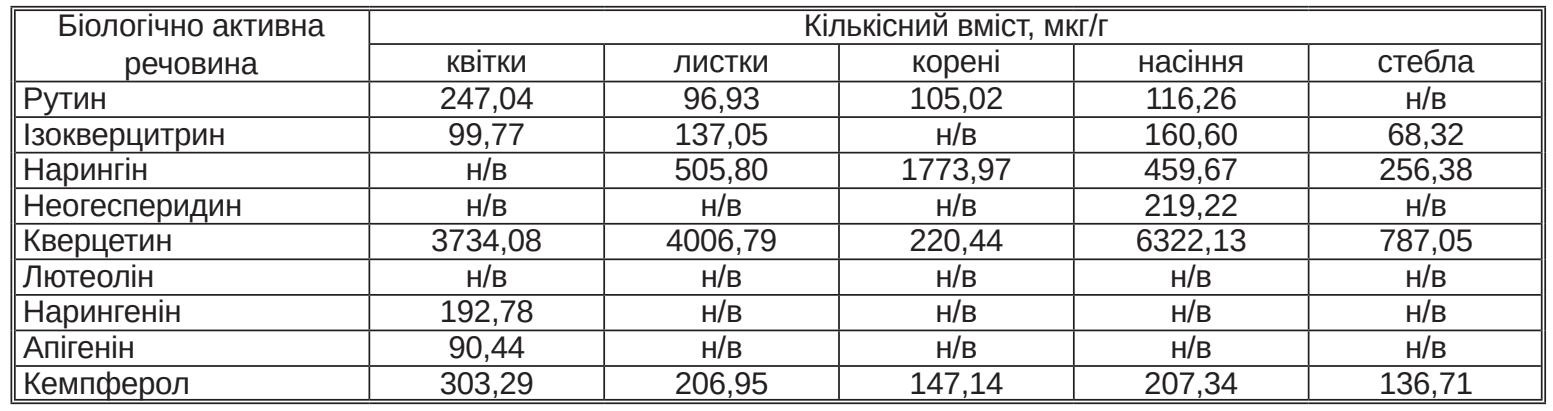

Примітка. н/в - не виявлено.

Таблиця 2 - Кількісний вміст суми фрлавоноїдів у сировині чорнобривців золотистих (спектросоотометричний метод)

\begin{tabular}{||l|c||}
\hline \multicolumn{1}{|c|}{ Назва сировини } & Вміст суми фрлавоноїдів, \%, $\mathrm{n}=5$ \\
\hline Квітки & $4,15 \pm 0,18$ \\
\hline Листки & $6,58 \pm 0,12$ \\
\hline Корені & $3,54 \pm 0,05$ \\
\hline Насіння & $7,89 \pm 0,18$ \\
\hline Стебла & $1,86 \pm 0,08$ \\
\hline
\end{tabular}

ВИСНОВКИ. 1. У результаті проведення реакцій ідентифрікації встановлено наявність орлавоноїдів у чорнобривців золотистих квітках, листках, коренях, насінні й стеблах. Методом тонкошарової хроматограсрії у досліджуваній сировині виявлено кверцетин, кемпорерол, рутин (крім стебел), ізокверцитрин (крім коренів), апігенін (лише у квітках).

2. Методом високоефективної рідинної хроматографрії встановлено якісний склад та визначено кількісний вміст індивідуальних фрлавоноїдних сполук. У чорнобривців золотистих квітках та насінні виявлено по 6 індивідуальних орлаво- ноїдів, у листках - 5, у коренях і стеблах - по 4. Найбільше у досліджуваних об'єктах виявлено кверцетину.

3. Спектрофротометричним методом визначено кількісний вміст суми фрлавоноїдів у сировині чорнобривців золотистих. Найвищий він у насінні - $(7,89 \pm 0,18) \%$, дещо нижчий у листках $(6,58 \pm 0,12) \%$.

4. Отримані результати свідчать про перспективність дослідження чорнобривців золотистих з метою створення на основі їх біологічно активних речовин нових лікарських засобів. 


\section{СПИСОК ЛІТЕРАТУРИ}

1. Гудзенко А. В. Вітчизняний ринок багатокомпонентних лікарських засобів рослинного походження: аналіз стану, структура та перспективи розвитку / А. В. Гудзенко, О.О.Цуркан, Т. В. Ковальчук // Фармац. журн. - 2012. - № 1. - С. 8-12.

2. Баула О. П. Забезпечення якості лікарських засобів рослинного походження: стан та перспективи / О. П. Баула, Т. М. Деркач // Фармац. часоп. - 2017. № 2. - С. 79-86.

3. Определение фрлавоноидов и гидроксикоричных кислот в траве Tagetes erecta L., Tagetes patula L. и Tagetes tenuifolia Cav. методом ВЭЖХ [Электронный ресурс] / С. М. Марчишин, Т. С. Бердей, С. С. Козачок, О. Л. Демыдяк // Медицина и образование в Сибири. 2013. - № 6. - Режим доступа : http://www.ngmu.ru/ cozo/mos/article/text_full.php?id=1205.

4. Бердей Т. С. Дослідження жовчогінної дії сухого екстракту трави чорнобривців у інтактних щурів / Т. С. Бердей, О. Ю. Кошова // Актуальні питання експериментальної і клінічної біохімії та фрармакології : матеріали Всеукр. наук.-практ. конфр. (Тернопіль, 9-10 жовт. 2014 р.). - Тернопіль, 2014. - С. 111.

5. Phytochemicals and their biological activities of plants in tagetes L. / X. U. Li-wei, C. Juan, Q. I. Huanyang, S. H. I. Yan-ping // Chin. Herb. Med. - 2012. № 4 (2). - P. 103-117.

6. Машковська С. П. Чорнобривці - джерело есрективних ліків / С. П. Машковська, І. П. Григорюк // Фітотерапія. Часопис. - 2003. - № 4. - С. 41-47.

7. Машковська С. П. Флавоноїди інтродукованих видів Tagetes L. / C. П. Машковська //Актуальні проблеми ботаніки та екології : матеріали конфр. молодих вчених-ботаніків України (Зноб-Новгородське, Національний природний парк “Деснянсько-Старогутський, 20-23 серп. 2001 р.). - Ніжин : Вид-во ТОВ Наука-СерBic, 2001. - С. 93.

8. Малюгіна О. О. Визначення кількісного вмісту фрлавоноїдів у суцвіттях чорнобривців розлогих і прямостоячих / О. О. Малюгіна, О. В. Мазулін, Г. В. Мазулін // Запорож. мед. журн. - 2013. - № 6 (81). C. 88-91.

9. Phenolic compounds of Tagetes lucida Cav. with antibacterial effect due to membrane damage / P. Y. Villa-Silva, A. lliná, J. A. Ascacio-Valdés [et al.] // Boletin latinoamericano y del caribe de plantas medicinales y aromáticas. - 2020. - No. 19 (6). - P. 580-590.
10. Berdei T. The content of flavonoids and hydroxycinnamomic acids in the herb of the plants from genus Tagetes L. $3^{\text {rd }}$ international conference and workshop / T. Berdei, L. Stoyko // Plant - the source of research material. Lublin, 2013. $-\mathrm{P} 77$.

11. Флавоноиды: биохимия, биосризика, медицина / Ю. С. Тараховский, Ю. А. Ким, Б. С. Абдрасилов, Е. Н. Музафаров ; [отв. ред. Е. И. Маевский]. - Пущино : Synchrobook, 2013. - 310 c.

12. Цикало Т. О. Дослідження фенольних сполук рижію посівного (Camelina sativa (L.) Crantz) та рижію дрібноплодого (Camelina microcarpa Andrz.) / Т. О. Цикало, С. Д. Тржецинський // Фармац. часоп. - 2020. № 4. - C. 18-24.

13. Determination of amino acids content of the Tagetes lucida Cav. by GC/MS / L. Slobodianiuk, L. Budniak, S. Marchyshyn, L. Kostyshyn, M. Ezhne // Pharmacia. - No. 68 (4). - P. 859-867.

14. Essential oils of herbs of some species of marigold genus (Tagetes L.) / L. Kostyshyn, T. Valko, S. Marchyshyn, S. Mashkovska // 1st Natural Cosmetics International, Rzeszów, Poland September 22nd-24th 2021. P. 61.

15. Державна Фармакопея України / дп “Український науковий фрармакопейний центр якості лікарських засобів". - 2-ге вид., доп. 1. - Х. : Держ. п-во "Український науковий фрармакопейний центр якості лікарських засобів", 2016. - 360 с.

16. Марчишин С. М. Визначення фрлавоноїдів тирличу хрещатого трави (Gentiana cruciata L.) / С. М. Марчишин, Л. І. Стойко, Л. М. Мосула // Фітотерапія. Часопис. - 2018. - № 2. - С. 58-61.

17. Marchyshyn S. Investigation of phenolic compounds of Antennaria dioica (L.) Gaertn. Herb / S. Marchyshyn, R. Basaraba, T. Berdey // The Pharma Innovation Journal. - 2017. - No. 6 (8). - P. 9-11.

18. Investigation of phenolic compounds of the leaves of Crambe cordifolia Steven and Crambe koktebelica (Junge) N. / S. Marchyshyn, O. Skrynchuk, L. Budniak, L. Mosula // The Pharma Innovation Journal. - 2020. No. 9 (1). - P. 14-17.

19. Pyrzynska K. Chromatographic analysis of polyphenols. polyphenols in plants / K. Pyrzynska, A. Sentkowska. - Academic Press, 2019. - P. 353-364.

\section{REFERENCES}

1. Hudzenko, A.V., Tsurkan, O.O., \& Kovalchuk, T.V. (2012). Domestic market of multicomponent medicines of plant origin: analysis of the state, structure and prospects of development. Pharmaceutical Journal, 1, 8-12 [in Ukrainian].

2. Baula, O.P., \& Derkach, T.M. (2017). Quality assurance of herbal medicines: status and prospects. Pharmaceutical Journal, 2, 79-86 [in Ukrainian].
3. Marchyshyn, S.M., Berdei, T.S., Kozachok, S.S., \& Demydyak, O.L. (2013). Determination of flavonoids and hydroxycinnamic acids in the herb Tagetes erecta L., Tagetes patula L. and Tagetes tenuifolia Cav. HPLC method. Medicine and education in Siberia, 6. Retrieved from: http://www.ngmu.ru/cozo/mos/article/text_full. php?id=1205. [in Russian]. 
4. Berdei, T.S., \& Koshova, O.Yu. (2014). Investigation of the choleretic effect of dry extract of marigold grass in intact rats. Current Issues of Experimental and Clinical Biochemistry and Pharmacology. October 9-10: Materials of the All-Ukrainian Scientific-Practical Conference. Ternopil [in Ukrainian].

5. Li-wei, X.U., Juan, C., Huan-yang, Q.I., Yanping, S.H.I. (2012). Phytochemicals and their biological activities of plants in Tagetes L. Chin. Herb. Med., 4 (2), 103-117.

6. Mashkovska, S.P., \& Hryhoriuk, I.P. (2003). Marigold - a source of effective drugs. Phytotherapy. Review, 4, 41-47 [in Ukrainian].

7. Mashkovska, S.P. (2001). Flavonoids of introduced species Tagetes L. Actual problems of botany and ecology. Materials of Conference of Young botanists of Ukraine (August 20-23 Znob-Novhorod). Nizhyn: NaukaServis LLC [in Ukrainian].

8. Maliuhina, O.O., Mazulin, O.V., \& Mazulin, H.V. (2013). Determination of the quantitative content of flavonoids in the inflorescences of marigold spreading and erect. Zaporizhzhia Medical Journal, 6 (81), 88-91 [in Ukrainian].

9. Villa-Silva, P.Y., Iliná, A., Ascacio-Valdés, J.A. (2020). Phenolic compounds of Tagetes lucida Cav. with antibacterial effect due to membrane damage. Boletin latinoamericano y del caribe de plantas medicinales y aromáticas, 19 (6), 580-590.

10. Berdei, T., \& Stoyko, L. (2013). The content of flavonoids and hydroxycinnamomic acids in the herb of the plants from genus Tagetes $L$. $3^{\text {rd }}$ international conference and workshop. Plant - the source of research material. Lublin.

11. Tarakhovsky, Yu.S., Kim, Yu.A., Abdrasilov, B.S., \& Muzafarov, E.N. (2013). Flavonoids: biochemistry, biophysics, medicine. Pushchino: Sunchrobook [in Russian].

12. Tsykalo, T.O., \& Trzhetsinsky, S.D. (2020). Investigation of phenolic compounds of ryegrass (Camelina sativa (L.) Crantz) and ryegrass (Camelina microcarpa Andrz.). Pharmaceutical Review, 4, 18-24 [in Ukrainian].

13. Slobodianiuk, L., Budniak, L., Marchyshyn, S., Kostyshyn, L., \& Ezhne, M. Determination of amino acids content of the Tagetes lucida Cav. by GC/MS. Pharmacia, 68 (4), 859-867.

14. Kostyshyn, L., Valko, T., Marchyshyn, S., \& Mashkovska, S. (2021). Essential oils of herbs of some species of marigold genus (Tagetes L.). 1st Natural Cosmetics International, Rzeszów, Poland September 22-24.

15. (2016). State Pharmacopoeia of Ukraine. Ukrainian Scientific Pharmacopoeial Center for Quality of Medicines. 2nd ed. Kharkiv: State Ukrainian Scientific Pharmacopoeial Center for Drug Quality [in Ukrainian].

16. Marchyshyn, S.M., Stoyko, L.I., \& Mosula, L.M. (2018). Determination of flavonoids of yarrow (Gentiana cruciata L.). Phytotherapy. Review, 2, 58-61 [in Ukrainian].

17. Marchyshyn, S., Basaraba, R., \& Berdey, T. (2017). Investigation of phenolic compounds of Antennaria dioica (L.) Gaertn. Herb. The Pharma Innovation Journal, 6 (8), 9-11.

18. Marchyshyn, S., Skrynchuk, O., Budniak, L., Mosula, L. (2020). Investigation of phenolic compounds of the leaves of Crambe cordifolia Steven and Crambe koktebelica (Junge) N. The Pharma Innovation Journal, 9 (1), 14-17.

19. Pyrzynska, K., \& Sentkowska, A. (2019). Chromatographic analysis of polyphenols. Polyphenols in Plants. Academic Press.

\section{RESEARCH OF FLAVONOIDS OF SWEET-SCENT MARIGOLD (TAGETES LUCIDA CAV.)}

\section{Summary}

Introduction. A promising source of new drugs are species of the genus Tagetes, which are cultivated in Ukraine as a technical and ornamental plant. Medicinal properties of marigold are used in traditional medicine as an immunosuppressant, anti-inflammatory, hypoglycemic, choleretic and sedative agent. Sweet-scent marigold (Tagetes lucida Cav.) is the little-studied species of the genus Tagetes, which was introduced into culture of Ukraine by scientists from the Department of Flowering and Ornamental Plants of M. M. Hryshko National Botanical Garden of the National Academy of Sciences of Ukraine (Kyiv).

The aim of the study - to research and compare the content of flavonoids in raw materials (flowers, leaves, roots, seeds, stems) of sweet-scent marigolds.

Research Methods. Flavonoids were detected in ethanol-aqueous extracts by identification reactions and TLC method. The quantitative content of the sum of flavonoids was determined on UV-1800 Shimadzu spectrophotometer (Japan) at a wavelength of $415 \mathrm{~nm}$ in terms of rutin. HPLC on Agilent 1200 chromatograph (Agilent Technologies, USA) detected and quantified individual flavonoid compounds. 
Results and Discussion. Positive results of identification reactions indicated the presence of flavonoids in the raw material of sweet-scent marigold. The presence of quercetin and kaempferol in flowers, leaves, roots, seeds and stems was established by TLC. Rutin is found in all studied raw materials, except for stems. The HPLC method revealed 6 individual flavonoids in marigold's flowers and seeds, 5-in leaves, 4 - in roots and stems. Most quercetin was detected in the studied objects. In seeds, leaves and flowers, its content was the highest and was $6322.13 \mu \mathrm{g} / \mathrm{g}$, $4006.79 \mu \mathrm{g} / \mathrm{g}$ and $3734.08 \mu \mathrm{g} / \mathrm{g}$, respectively. All types of raw material of marigold also contained kaempferol, which was the biggest part in flowers - $303.29 \mathrm{mcg} / \mathrm{g}$. The spectrophotometric method determined that the highest content of the amount of flavonoids was contained in the seeds of sweet-scent marigold and was $(7.89 \pm 0.18) \%$, the least of them in the stems $-(1.86 \pm 0.08) \%$.

Conclusions. Identification reactions revealed the presence of flavonoids in marigold's flowers, leaves, roots, seeds and stems. TLC revealed quercetin, kaempferol, rutin (except stems), isoquercitrin (except roots), apigenin (flowers only). By HPLC, 6 individual flavonoids were found in marigold's flowers and seeds, 5 - in leaves, and 4 in roots and stems. Most quercetin was detected in the studied objects. The quantitative content of the sum of flavonoids in the raw material of sweet-scent marigold was determined by spectrophotometric method. Their highest content in seeds was $(7.89 \pm 0.18) \%$, slightly lower, which was $(6.58 \pm 0.12) \%$, in the leaves.

KEY WORDS: sweet-scent marigolds (Tagetes lucida Cav.); flavonoids; thin layer chromatography; high performance liquid chromatography; spectroscopy.

Отримано 05.11.21

Адреса для листування: С. М. Марчишин, Тернопільський національний медичний університет імені І. Я. Горбачевського моз України, майдан Волі, 1, Тернопіль, 46001, Україна, e-mail: marchyshyn@tdmu.edu.ua. 